\title{
Currency Options, Implied Interest Rates and Inflation Targeting
}

\author{
Helena G. Keefe ${ }^{1} \&$ Erick W. Rengifo ${ }^{2}$ \\ ${ }^{1}$ Department of Economics, Fairfield University, Fairfield, CT, USA \\ ${ }^{2}$ Department of Economics, Fordham University, Bronx, NY, USA \\ Correspondence: Helena G. Keefe, Department of Economics, Fairfield University. Donnarumma Hall 327. 1073 \\ N. Benson Rd. Fairfield, CT, 06482 USA. Tel: 1-203-254-4000 ext. 2036. E-mail: hkeefe@ fairfield.edu
}

Received: December 11, 2018

Accepted: January 11, 2019

Online Published: January 15, 2019

doi:10.5539/ijef.v11n2p119

URL: https://doi.org/10.5539/ijef.v11n2p119

\begin{abstract}
The currency option price is a powerful tool used regularly to determine market expectations on volatility in currencies using the implied volatility measure. This research tests and analyzes whether similar inferences can be made regarding interest rate and inflation expectations. Using historical options data, we derive and analyze implied interest rates during non-inflation targeting (non-IT) and inflation targeting (IT) periods for Australia, Canada, and the United Kingdom. We compare the results to a control group of countries that had not yet adopted inflation targeting during the period under study: Germany, Japan and Switzerland. Our results show that options prices can provide insights on market expectations on interest rates, that the adoption of inflation targeting strengthens the relationship between market expectations and inflation, and that shocks in interest rates and inflation lead to higher implied interest rates. In determining the potential uses of implied interest rates derived from currency options prices, our goal is not to replace the Federal Funds futures or equivalent tools in advanced economies, rather to present the usefulness of currency options as a tool to provide information to policymakers in emerging market economies. Central banks, such as the Banco Central de Colombia and Banco de Mexico, have been using currency options as tools for foreign exchange intervention or reserve accumulation/decumulation since the early 2000 's, and options markets in these economies have grown rapidly since then. Therefore, establishing the usefulness of implied interest rate measures derived from currency options prices may provide insights to policymakers and practitioners alike.
\end{abstract}

Keywords: currency options, inflation targeting, financial markets, market expectations, interest rates

\section{Introduction}

Currency options provide a wealth of information on market participants' expectations that can be leveraged by policymakers to gain insights on market conditions. Most notably, practitioners regularly rely on implied volatility measures to gauge expectations of movement in the underlying asset value. In currency options, this translates to expectations on volatility in exchange rates. In this paper, we present how the approach of measuring "implied" variables from currency option prices can be used by policymakers to gauge expectations on domestic interest rate movements and on inflation expectations, measures that are currently unavailable at a high frequency through survey data (Note 1).

In advanced economies, there are reliable sources such as the Federal Funds futures contracts to estimate these market expectations. However, equivalent reliable sources do not exist in emerging market economies. In studying and determining the potential uses of implied interest rates derived from currency options prices, our goal is not to replace the Federal Funds futures or equivalent tools in advanced economies, rather to present the usefulness of currency options as a tool to provide information to policymakers in emerging market economies. Central banks, such as the Banco Central de Colombia and Banco de Mexico, have been using currency options as tools for foreign exchange intervention or reserve accumulation/decumulation since the early 2000's. Colombia's use of volatility options has proven to be an effective tool in controlling exchange rate volatility (Keefe \& Rengifo, 2015).

Moreover, the options market has been growing rapidly in emerging economies. From the Bank of International Settlements' 2016 Triennial Report on Foreign Exchange and Derivatives, currency options in emerging economies have grown $48 \%$ from 2010 to 2016, and account for $19 \%$ of all options traded in foreign exchange markets (compared to 13\% in 2010) (Note 2). As the currency option market continues to grow in these economies, 
the research presented in this paper will aid policymakers in making the most out of the information they have available through development of these markets.

The use of such implied variables on interest rate movements and inflation expectations may be particularly appealing in economies that have adopted inflation targeting as the main monetary policy goal. There are several changes that occur once an economy adopts inflation targeting. First, under greater transparency and clear commitment to a specific target by the central bank, market participants are now able to anticipate actions by policymakers to maintaining the inflation target. Therefore, in their pricing decisions, market participants will factor in the anticipated policy changes to interest rates and consideration for inflation expectations. Second, the credibility of the central bank improves as it continues to act to maintain the stated targets. Lastly, low inflation under the inflation targeting regimes has been found to improve economic growth (Mishkin \& Posen, 1998).

The main goal of the research presented in this paper is to determine whether currency options can be used to estimate implied domestic interest rate movements and thereby infer market expectations, whether differences in reliability exist in inflation targeting (IT) versus non-inflation targeting (non-IT) periods, and what implications this may have for policymakers, particularly in emerging market economies that are focused on developing deeper financial and risk markets. We use historical option pricing data (Note 3) for Australia, Canada, and United Kingdom as countries that adopted inflation targeting during the period under study. We compare these results to implied interest rate measures in Germany, Japan, and Switzerland. We focus on these advanced economies to test our hypotheses since access to data on currency options in emerging markets is limited (Note 4).

The rest of the paper is arranged as follows: Section 2 presents a review of the literature, Section 3 addresses the model and methodology, Section 4 presents the empirical results, and Section 5 concludes.

\section{Literature Review}

In recent years, there have been a number of empirical studies looking to derive market expectations on monetary policy rules using various financial instruments. Soderlind and Svensson (1997) survey the effectiveness of various methods to extract market expectations on monetary policy from asset prices. Asset prices provide a wealth of information for policymakers, including up-to-date reflection of macroeconomic data, aberrations indicating imperfections or manipulation in financial systems, and most importantly, the expectations of market participants. They find that financial tools can be effective in extracting market expectations on interest rates, inflation and exchange rates. However, such inference relies on the development and depth of financial markets, as well as the level of financial integration.

Gurkayank, Sack, and Swanson (2007) test the success of various financial instruments in predicting future monetary policy, and find that all are more effective than the traditional forecasting approaches. Their study is specific to the use of US-based financial tools, including the federal funds rate, which they find to be the most successful predictor for the short run. Many others have also attempted to parse out market expectations from financial instruments, such as Kuttner (2001), Faust, Swanson, and Wright (2004), Bomfim (2003) and Poole and Rasche (2000) who use federal funds futures contracts. Other financial tools, such as the one month euro-dollar deposit rate, the three-month treasury bill rate, and the three-month euro-dollar futures rate, have been tested by Cochrane and Piazzesi (2002), and Ellingsen and Soderstrom (2004) and Rigobon and Sack (2002), respectively.

The use of currency options to gauge market expectations has focused primarily on implied volatility to determine market expectations of exchange rate movements. Yet, options prices can provide additional predictive value. Bates (1991) demonstrates how equity options prices may have predicted the 1985-1987 crash, when out-of-the-money puts became unusually expensive. The expectation of a market crash was built into the option price, pushing up the value of the put options. Hui and Fong (2015) present the impact of sovereign risk on market expectations of exchange rates through its effect on currency options prices in developed economies, and demonstrate how the implied volatility and options prices change under risk-reversals quoted in the options market. Han, Liang, and Wu (2016) use currency options for three major advanced economy currencies (Euro, British Pound, and Swiss Franc) to determine the relationship between options prices and real economic variables across the countries, showing that the contemporaneous default spreads, domestic and cross country spot market trends as well as historical volatility in the spot and stock markets all impact the implied volatility smile.

Sihvonen and Vahamma (2014) use UK interest rate options to demonstrate how market participants accurately price in Libor expectations that align with policy rule variables, and that changes in the expectations reflected in the price are associated with changes in expected inflation and output gap. Carlson et al. (2005) use the federal funds futures options to extract the implied probably distribution for the Federal Reserve's target policy rate, thereby testing the effects of announcements on market expectations. Hong and Yogo (2012) demonstrate that the amount of futures contracts outstanding, or open interest, contain important information about future 
economic activity that is not always captured in the price. Vahamma, Watzka, and Aijo (2005) present the impact of surprise macroeconomic announcements on bond future options, extracting market expectations from the option price and showing how bond volatilities increase with higher-than-expected inflation or unemployment announcements.

Kumar, Afrouzi, Coibion, and Gorodnichenko (2015) note that market expectations on inflation do not differ significantly after the adoption of inflation targeting. In studying firms' expectations in New Zealand, the authors find that managers were poorly informed about the central bank's objectives as well as about inflation dynamics, and therefore did not pin their inflation expectations to inflation targeting by the central bank. In contrast, Davis (2014), finds notable differences in the anchoring of inflation expectations in the inflation targeting period after various economic shocks across the surveyed countries. The change in expectations was much less significant and less persistent after the adoption of inflation targeting. Capistran and Ramos-Francia (2010) find that the dispersion of inflation forecasts is smaller under inflation targeting regimes across fourteen inflation targeting countries. Arizmendi (2013) merges the inflation targeting model proposed by Taylor (1993) and Molodtsova and Papell (2012) with the Garman-Kohlhagen option pricing model. He demonstrates how the target interest rate can be incorporated directly into the option price, allowing the option price to reflect the domestic interest rate targets and the inflation targets of the central bank. In contrast, in this paper, we look to solve for the implied interest rate to infer market expectations on interest rate movements from the option price.

\section{Model and Methodology}

In this section, we present the case for how the inflation targeting policy rate can be incorporated in the option price and from there how it is possible to determine implied interest rate. Implied volatility is a measure frequently calculated and used by market participants to gauge future expectations of a stock's or currency's volatility based on the option's price. It provides forward-looking insight on where the market believes volatility will be in the future. It is possible to link the option price with interest rate expectations using the same sentiment to determine the implied interest rate. By using currency option prices, the model reverse-engineers the Garman-Kohlhagen option pricing model to determine the expectations of market participants on future interest rate movements.

\subsection{Model}

According to Arizmendi (2013), it is possible to merge the inflation targeting model with the Garman-Kohlhagen option pricing model, allowing the central bank totarget the domestic interest rate as follows:

$$
i_{t}=\pi_{t}+\beta_{1}\left(\pi_{t}-\pi_{e}\right)+\beta_{2} Y_{t}+r
$$

where $i_{t}$ is the domestic policy target interest rate, $\pi_{t}$ is actual inflation rate, $\pi_{e}$ is the expected inflation rate, $Y_{t}$ is the output gap (potential vs. actual real GDP), and $r$ is the equilibrium real interest rate. To control for the quasi-perfect multicollinearity between the domestic interest rate and inflation rate that would be found in Equation (1), the following equation is used to conduct the regression to determine the coefficients and estimate the target domestic interest rate to be used in the option price:

$$
i_{t}^{r}=i_{t}-\pi_{t}=r+\beta_{1}\left(\pi_{t}-\pi_{e}\right)+\beta_{2} Y_{t}+E
$$

thereby estimating the real domestic policy target interest rate, assuming $E$ is i.i.d normal error term. To recover the domestic nominal target interest rate, one can adjust for $\pi_{t}$ after determining the coefficients and estimate $i_{\text {target }}$ as:

$$
i_{\text {target }}=r+\left(1+\beta_{1}\right) \pi_{t}-\beta_{1} \pi_{e}+\beta_{2} Y_{t}
$$

The target domestic nominal interest rate can then be included in the Garman-Kohlhagen option pricing model by replacing the domestic interest rate $i_{d}$. The Garman-Kohlhagen option pricing model determines the option price as follows (Garman \& Kohlhagen, 1983):

$$
C=S_{0} e^{-i \mathcal{f} \tau} \Phi(d 1)-K e^{-i d \tau} \Phi(d 2)
$$

where $C$ is the value of the call options, and:

$$
P=K e^{-i d \tau} \Phi(-d 2)+S_{0} e^{-i \boldsymbol{f} \tau} \Phi(-d 1)
$$

determines the value of the put option $(\mathrm{P})$.

$$
\begin{gathered}
d 1=\frac{\ln \left(\frac{S_{0}}{K}\right)+\left(i_{d}-i_{f}+\frac{\sigma^{2}}{2}\right) \tau}{\sigma \sqrt{\tau}} \\
d 2=d 1-\sigma \sqrt{t}
\end{gathered}
$$


where $\tau=T-t$, or time to maturity, $\Phi$ is the standard normal distribution function, $\sigma$ is the volatility of the underlying asset, $i_{d}$ and $i_{f}$ are the domestic interest rate and foreign risk free interest rates. $S_{t}$ is the spot rate at time $t, S_{0}$ is the spot rate at the beginning of the contract, and $K$ is the strike price.

Once the options are sold, the central bank can infer expectations of market participants by observing the difference between the model estimated premium and the one which is executed in the market. From the actual premium values, one can derive the "implied interest rate", reflecting market expectations based on the option price determined by the market. We can derive the implied domestic interest rate as follows:

$$
\begin{gathered}
i c *=\frac{1}{\mathrm{t}}\left[\ln (K)+\ln (\Phi(d 2))-\ln \left(S 0 e-i \boldsymbol{F}^{\boldsymbol{\tau}} \Phi(d 1)-C m\right)\right] \\
i p *=\frac{1}{\mathrm{t}}\left[\ln (K)+\ln (\Phi(d 2))-\ln \left(S 0 e-i \boldsymbol{F}^{\boldsymbol{\tau}} \Phi(d 1)+P m\right)\right]
\end{gathered}
$$

where ic $*$ is the implied interest rate derived from the call option market price $(\mathrm{Cm})$, and ip $*$ is the implied interest rate derived from the put option market price $(\mathrm{Pm})$. We assume that the foreign interest rate, as well as the other components of the pricing model, are exogenous, allowing the model to isolate the implied domestic interest rate measure.

This model provides a means to gauge market expectations based on the actions of market participants rather than survey reports.5 Central banks can judge whether actual market expectations significantly differ from reported expectations and adjust their policies accordingly. In addition, this approach allows central banks and market participants to make inferences about macroeconomic and monetary variables from the actions of traders, rather than survey reports from other market participants.

\subsection{Methodology}

To test the analytical capabilities of the implied interest rate calculated from the Garman-Kohlhagen (GK) model, we use option pricing data from 1987 to 1997 for six advanced economy currencies. This period of study is chosen to encompass currency options issued prior to the adoption of inflation targeting (1987-1993) and compare to currency options issued after the adoption of inflation targeting (1993-1997). Data is collected from the Philadelphia Stock Exchange and reported by the Wharton School of Business WRDS database. Option pricing data is only available from 1987 to 1997 from this source and only for advanced economies. Accessing recent currency options data is prohibitively expensive through private sources. Currency option data for emerging markets and recent data for advanced economies is not available on sources such as Bloomberg, WRDS, or other databases typically available to academics. Relying this historical dataset does not detract from the conclusions we are able to draw from the currency options data on implied interest rates and market expectations. As will be presented below, the period under study is ideal as it captures the pre- and post-IT periods for the advanced economies.

The first three countries adopted inflation targeting monetary policy between 1987 and 1997. These are Australia (Australian Dollar-US Dollar or XAD), Canada (Canadian Dollar-US Dollar or XCD) and United Kingdom (British Pound-US Dollar or XBP). Australia adopted inflation targeting in 1993, Canada in 1991, and UK in 1992. We split the data for these countries into the period before inflation targeting was adopted (non-inflation targeting period or NIT) and the inflation targeting period (IT). For Australia, the non-IT period starts on January 21, 1987 and ends on May 31, 1993, the IT period begins on June 1, 1993 and ends on December 31, 1997. For UK, the non-IT period begins on January 2, 1987 and ends on April 30, 1992, the IT periods begins on October 6, 1992 and ends on December 31, 1997. For Canada, the non-IT period begins on January 2, 1987 and ends on January 31, 1991, the IT period begins on February 1, 1991 and ends on December 31, 1997.6

We compare the outcomes to a control group of countries which had not adopted inflation targeting between 1987 and 1997. These include Germany (Deutche Mark - US Dollar or XDM), Japan (Yen - US Dollar or XJY) and Switzerland (Swiss Franc - US Dollar or XCF). We segment the data for these countries into two periods: January 1, 1987 to December 31, 1992 and January 1, 1993 to December 31, 1997. The samples align with the non-IT and IT periods for the IT countries mentioned above. In segmenting the data for the control group, we are testing whether the adoption of inflation targeting in the IT countries itself was a factor in changing the analytical capability of the implied interest rate, or if rather the further development and depth in options markets during the latter period is responsible for any changes.

To calculate the implied interest rate for each country, we use the strike price $(\mathrm{K})$, spot price at closing (S), time to maturity, market option price $\left(C_{m}\right.$ or $\left.P_{m}\right)$ (Note 7) reported from the Philadelphia Stock Exchange. We use the Federal Funds rate as the foreign interest rate $\left(i_{f}\right)$. We calculate volatility as the 10 day volatility based on historical exchange rates, specifically the standard deviation of the log difference of the spot rate over 10 days (Note 8). Wecalculate $i^{*}$ according to Eq. (8) above. We use short-term options with maturities of 20 to 45 days. 
We then test the stationarity of the implied interest rate $\left(i^{*}\right)$, the reported domestic interest rate $\left(i_{d}\right)$, and inflation $(\pi)$ using the Augmented Dickey Fuller test. This is followed by testing for cointegration relationships using the Johansen test in the non-inflation targeting and inflation targeting periods separately, and the corresponding periods for the control group. Our goal in analyzing the cointegration is to verify the possible existence of long-term relationships between the variables and whether these relationships change with the adoption of inflation targeting policies. The first Johansen Cointegration test is conducted for the implied interest rate $\left(i^{*}\right)$, the reported domestic interest rate $\left(i_{d}\right)$, and inflation $(\pi)$. A second Johansen Cointegration test is conducted only for the implied interest rate and inflation.

Based on the outcomes of the cointegration test, we employ the Vector Error Correction (VEC) model to test the relationships between $i^{*}, i_{d}$, and $\pi$ and derive impulse response functions. The VEC model (VECM 1) is presented as follows:

$$
\Delta y_{t}=\alpha \beta^{\prime} y_{t-1}+\Gamma_{l} \Delta y_{t-1}+\ldots \Gamma_{p-1} \Delta y_{t-p+l}+u_{t}
$$

$\alpha \beta^{\prime} y_{t-1}$ represents the error correction term, and:

$$
\Gamma_{i}=-\left(A_{i+1}+\ldots+A_{p}\right), i=1, \ldots, p-1
$$

where $X_{1, t}$ represents the implied domestic interest rate, $X_{2, t}$ represents the reported target domestic interest rate, and $X_{3, t}$ represents the inflation rate. The $\alpha$ values in Equation (10) represent the speed to convergence or the adjustment parameters, which indicate how quickly the model converges. We are interested in comparing these values in the IT versus non-IT periods to determine whether the speed to convergence is quicker with the adoption of inflation targeting.

$$
A 1=\begin{array}{llr}
\Phi_{1,1} & \varphi_{1,2} \varphi_{1,3} & X_{1, t} \\
\Phi_{2,1} & \varphi_{2,2} \varphi_{2,3 ;} ; & y t=X_{2, t} \\
\Phi_{3,1} & \varphi_{3,2} \varphi_{3,3} & X_{3, t}
\end{array}
$$

Our goal is to test the relationship between the implied interest rate that is directly sourced from the observed option pricing data, the reported interest rate, and inflation rate. We rely on the Vector Error Correction Model because we are interested in capturing the linear interdependencies among the three variables. As we will present in Section 4, due to the presence of a cointegrating relationship, we opt for the VEC model over the Vector Autoregression Model (VAR). The impulse responses are presented as a means to report and interpret the results of the VEC model. They provide valuable insight into how the implied interest rate responds to shocks in the reported variables.

As a robustness test, we also conduct a bivariate VEC model (VECM 2) and a bivariate Vector Autoregression model (VAR) using the implied interest rate and inflation rate only. For the VAR model, we use the first difference of each variable to ensure stationarity. Using the three models, we forecast values for $i^{*}, i_{d}$ and inflation using a 10 -week window static forecast. We compare the results to the estimated implied interest rate, the reported domestic interest rate, and the reported inflation rate. By providing static forecasts, we are testing whether the model can offer additional information to policymakers interested in leveraging options for inferences on market expectations (Note 9).

\section{Results}

In this section, we present the estimations of the implied interest rate derived from the GK mode compared to the reported domestic interest rate. We then discuss the results for the cointegration tests, the impulse response functions based on the Vector Error Correction model, and finally the static forecasts of the implied interest rate, domestic interest rate and inflation rate.

Figure 1 presents the reported domestic interest rate compared to the estimated implied interest rate using the GK model for the countries that adopted inflation targeting between 1987 and 1997, as well as the inflation rates and corresponding options prices for each. The grey block represents the beginning of inflation targeting monetary policy. In the three IT countries, the implied interest rate is able to replicate the general trend of the reported domestic interest rate, yet in the non-IT period, the implied interest rate is consistently below the reported interest rate. In the IT period, however, the implied rates are much closer to the reported rates. This is especially true a year or two after monetary authorities have implemented inflation targeting, and when the market begins to incorporate the monetary policy commitment into options prices. The ability of the implied rate to track more closely to the actual rate may reflect market participants' stronger consideration of monetary policy actions and its implications on interest rate movements in the IT period. In this period, policymakers are dedicated to taking action through interest rate targets to meet inflation targeting goals, and market participants may be factoring this commitment into the option price. Figure 2 shows that the implied interest rate closely tracks the 
reported rate in the control group as well, except between June 1990 and June 1994 for Germany and Switzerland. In these periods, the implied interest rates are lower than the reported domestic interest rates. It is also important to note that this mismatch corresponds to a spike in inflation rates in each country, as can be seen in the middle graphs of Figure 2. During periods of high inflation (or spikes in inflation), the implied interest rate shows that market expectations tend to underestimate the domestic interest rate movements, seen in both Figure 1 and 2. Overall, the implied interest rate provides a decent estimation of the reported domestic interest rate when inflation rates are low. This can be seen across periods in both the IT countries and control group.

Australia

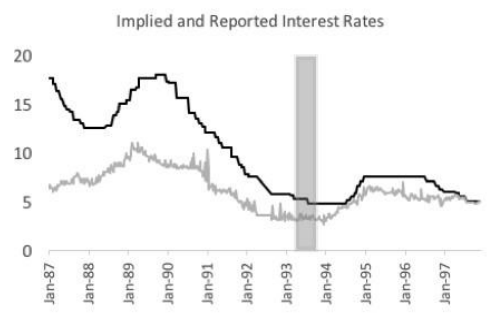

Canada
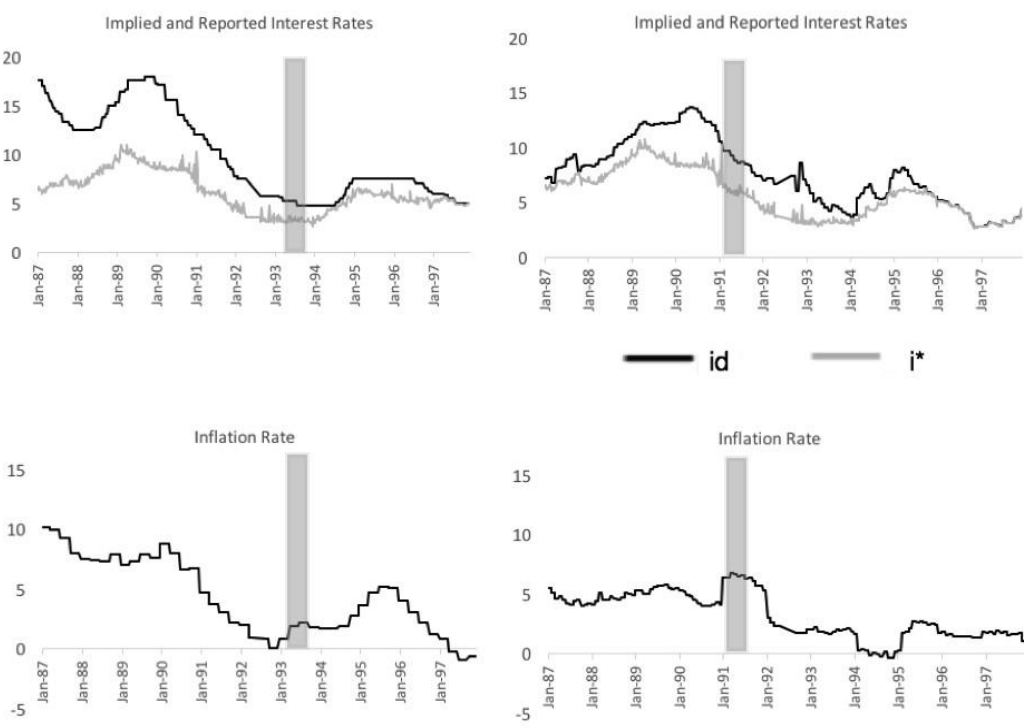

Options Price

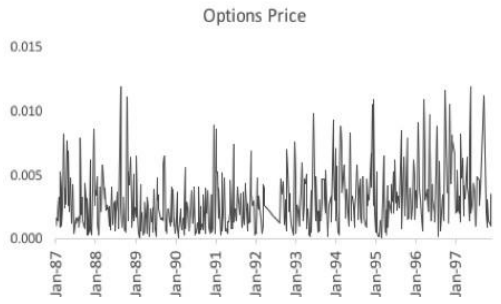

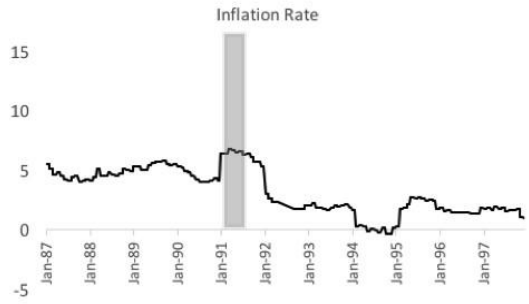

Options Price

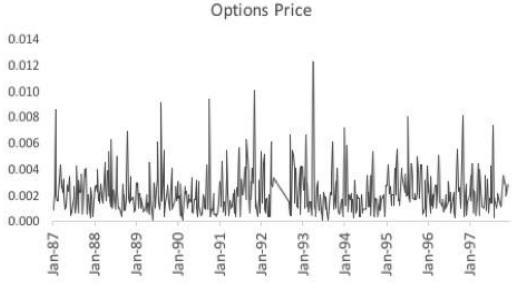

United Kingdom

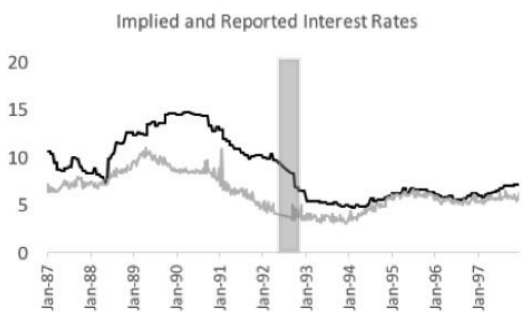

Figure 1. Reported interest rates and implied interest rates in IT countries

Note. This figure illustrates reported domestic interest rate compared to the implied interest rate derived from the GK option pricing model for the countries which adopted inflation targeting between 1987 and 1997. The grey block represents the adoption of inflation targeting. The middle graphs show the inflation rate in each country. The bottom graphs present the corresponding options prices.

After testing for stationarity in all three variables using the Augmented Dickey Fuller Test, we find that the implied interest rate $\left(i^{*}\right)$, the reported interest rate $\left(i_{d}\right)$ and the inflation rate $(\pi)$ are all non-stationary of degree 1 , which is presented in Table 1 . We test for cointegration in these three variables using the Johansen Cointegration Test, with results presented in Table 2 and Table 3. For the IT countries, we test the non-IT and IT periods separately to determine how the cointegrating relationship may differ in these two periods, especially if market participants are incorporating the monetary policy expectations into the option price in the IT period. 


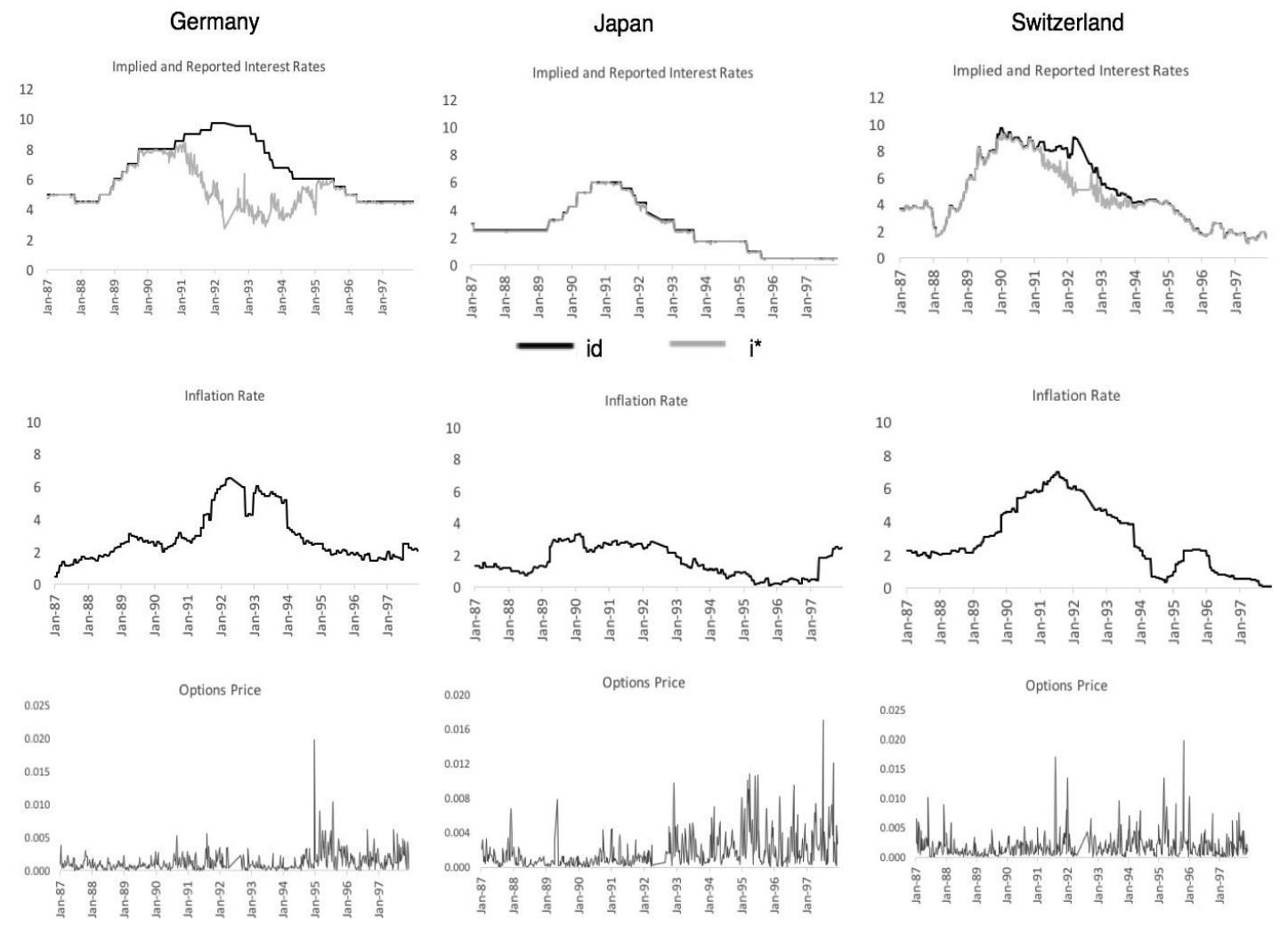

Figure 2. Reported interest rates and implied interest rates in control group

Note. This figure illustrates reported domestic interest rate compared to the implied interest rate derived from the GK option pricing model for the control countries, which did not adopt inflation targeting between 1987 and 1997. The middle graphs show the inflation rate in each country. The bottom graphs present the corresponding options prices.

Table 1. Augmented Dickey Fuller test for $i^{*}, i_{d}$ and inflation

\begin{tabular}{ccccccc}
\hline & \multicolumn{2}{c}{ Australia } & \multicolumn{2}{c}{ Canada } & \multicolumn{2}{c}{ United Kingdom } \\
\hline ADF Stat & Non-IT & IT & Non-IT & IT & Non-IT & IT \\
\hline id & 0.314 & -0.966 & -1.638 & -2.104 & -0.927 & -0.966 \\
& $(0.978)$ & $(0.756)$ & $(0.461)$ & $(0.243)$ & $(0.778)$ & $(0.765)$ \\
$i^{*}$ & -0.719 & -1.608 & -2.012 & -1.991 & -1.205 & -1.608 \\
& $(0.840)$ & $(0.478)$ & $(0.281)$ & $(0.291)$ & $(0.674)$ & $(0.478)$ \\
$\pi$ & -0.744 & -2.105 & -1.788 & -2.233 & -0.931 & -2.105 \\
& $(0.832)$ & $(0.243)$ & $(0.385)$ & $(0.195)$ & $(0.777)$ & $(0.243)$ \\
\hline \multicolumn{2}{c}{ Germany } & \multicolumn{2}{c}{ Japan } & Switzerland \\
\hline ADF Stat & $1987-1992$ & $1993-1997$ & $1987-1992$ & $1993-1997$ & $1987-1992$ & $1993-1997$ \\
\hline id & 0.142 & -2.467 & -0.866 & -2.822 & -0.940 & -1.248 \\
& $(0.968)$ & $(0.344)$ & $(0.797)$ & $(0.191)$ & $(0.774)$ & $(0.653)$ \\
$i^{*}$ & -0.464 & -2.203 & -0.879 & -2.987 & -1.306 & -0.970 \\
& $(0.895)$ & $(0.205)$ & $(0.793)$ & $(0.138)$ & $(0.629)$ & $(0.766)$ \\
$\pi$ & 0.834 & -1.858 & -1.134 & -0.927 & -1.600 & -1.819 \\
& $(0.994)$ & $(0.352)$ & $(0.702)$ & $(0.778)$ & $(0.790)$ & $(0.370)$ \\
\hline
\end{tabular}

Note. This table presents the results of the Augmented Dickey Fuller Test for implied interest rate (i*), the reported interest rate (id) and the inflation rate $(\pi)$ in the non-IT and IT periods for all countries. Results show the null hypothesis cannot be rejected for all cases, and therefore the series are non-stationary. Values in parenthesis represent p-values.

As can be seen from Table 2, there is at least one cointegration relationships in the non-IT period in Australia, Canada, and the UK. In the IT period, all three countries exhibit more than one cointegrating relationship among the variables. For the control group, there is only one cointegrating relationship be- tween the three variables, seen in Table 3. For Germany and Japan, this remains consistent in both two samples. For Switzerland, the cointegration relationship arises in the post-1993 period. To further dissect the relationship between market expectations on interest rates and inflation, Tables 4 and 5 test the cointegration relationship between in the 
implied interest rate and the inflation rate for the IT countries and control group respectively.

In Table 4, before the adoption of inflation targeting policies, there is no cointegration present between the implied interest rate and the inflation rate. Currency option prices in the pre-IT period do not indicate any long-run relationship with inflation. Yet, upon the adoption of inflation targeting monetary policies in the IT group of countries, a strong and statistically significant cointegration relationship arises between the options-based implied interest rate and the inflation rate. It appears that the market is now factoring in inflation as part of the pricing mechanism through expectations on interest rate movements. This is a critical finding in our research. Essentially, a long-run relationship between inflation and market expectations appears to be stronger once inflation targeting policies are introduced. It is important to note once again that the implied interest rate does not directly account for the inflation rate when estimated, rather it only uses market-derived information relevant to the option price. The cointegration between these two variables is picking up the response of market expectations to inflation via the implied interest rate. This relationship does not exist in the control group of countries, seen in Table 5, with the exception of Switzerland. In Germany and Japan, there is no cointegration between inflation and the implied interest rate measure in either period, whereas Switzerland exhibits a cointegration in the post-1993 period.

Switzerland is an interesting case. Although Switzerland had not formally adopted inflation targeting, during this period of time it conducted monetary policy with the express purpose of maintaining price stability (see Rich, 2003). Specifically, Switzerland was dedicated to medium-term monetary targeting of its monetary base, which proved to be an effective tool to keep inflation under control. It operated with transparency, regular communication to the public and clear commitment to price stability. These elements that critical to the success of inflation targeting regimes may help explain why the cointegration results for Switzerland are similar to the IT country results. In contrast, although Germany was also committed to price stability and conducted monetary targeting during this period of time, it targeted M3 rather than the monetary base. This approach was less effective in the 1990's as M3 began to act more as a financial asset than a medium of exchange, thereby providing less-than-ideal guidance for targeting (Federal Reserve Bank of New York, 1997).

Table 2. Johansen Cointegration test for IT countries between $i^{*}, i_{d}$ and inflation

\begin{tabular}{llllllllll}
\hline & \multicolumn{3}{l}{ Non-IT Period (XAD) } & \multicolumn{3}{l}{ Non-IT Period (XCD) } & \multicolumn{2}{l}{ Non-IT Period (XBP) } \\
\hline No. of CE(s) & Eigen & Trace & Prob. & Eigen & Trace & Prob. & Eigen & Trace & Prob. \\
\hline None & 0.125 & 43.890 & $0.001^{* * *}$ & 0.127 & 33.260 & $0.018^{* *}$ & 0.090 & 31.437 & $0.032^{* *}$ \\
At most 1 & 0.017 & 5.035 & 0.805 & 0.021 & 6.221 & 0.673 & 0.028 & 7.427 & 0.567 \\
At most 2 & 0.000 & 0.107 & 0.783 & 0.009 & 1.829 & 0.176 & 0.007 & 0.183 & 0.755 \\
\hline \multicolumn{4}{l}{ IT Period (XAD) } & \multicolumn{3}{l}{ IT Period (XCD) } & IT Period (XBP) \\
\hline No. of CE(s) & Eigen & Trace & Prob. & Eigen & Trace & Prob. & Eigen & Trace & Prob. \\
\hline None & 0.167 & 44.50 & $0.001^{* * *}$ & 0.051 & 29.79 & $0.037^{* *}$ & 0.189 & 66.35 & $0.001^{* * *}$ \\
At most 1 & 0.079 & 13.95 & $0.084^{*}$ & 0.039 & 15.49 & $0.044^{* *}$ & 0.026 & 11.43 & 0.186 \\
At most 2 & 0.002 & 0.252 & 0.728 & 0.015 & 4.382 & $0.036^{* *}$ & 0.017 & 4.520 & $0.034^{* *}$ \\
\hline
\end{tabular}

Note. This table presents the results of the Johansen Cointegration Test for implied interest rate (i*), the reported interest rate (id) and the inflation rate $(\pi)$ in the non-IT and IT periods for the countries that adopted inflation targeting between 1987 and 1997. ***, **, * represents rejection of the null hypothesis at the 1,5 , and $10 \%$ level respectively, indicating the existence of at least one cointegrating relationship.

Table 3. Johansen Cointegration test for control group between $i^{*}, i_{d}$ and inflation

\begin{tabular}{|c|c|c|c|c|c|c|c|c|c|}
\hline \multirow[b]{2}{*}{ No. of CE(s) } & \multicolumn{3}{|c|}{ 1987:1-1992:12 (XDM) } & \multicolumn{3}{|c|}{ 1987:1-1992:12 (XJY) } & \multicolumn{3}{|c|}{ 1987:1-1992:12 (XCF) } \\
\hline & Eigen & Trace & Prob. & Eigen & Trace & Prob. & Eigen & Trace & Prob. \\
\hline None & 0.094 & 30.71 & $0.039 * *$ & 0.200 & 61.44 & $0.001 * * *$ & 0.044 & 20.00 & 0.458 \\
\hline At most 1 & 0.020 & 5.469 & 0.762 & 0.020 & 6.359 & 0.675 & 0.031 & 8.606 & 0.454 \\
\hline \multirow[t]{2}{*}{ At most 2} & 0.002 & 0.387 & 0.677 & 0.006 & 1.353 & 0.310 & 0.002 & 0.556 & 0.613 \\
\hline & \multicolumn{3}{|c|}{ 1993:1-1997:12 (XDM) } & \multicolumn{3}{|c|}{ 1993:1-1997:12 (XJY) } & \multicolumn{3}{|c|}{ 1993:1-1997:12 (XCF) } \\
\hline No. of CE(s) & Eigen & Trace & Prob. & Eigen & Trace & Prob. & Eigen & Trace & Prob. \\
\hline None & 0.128 & 35.06 & $0.011 * *$ & 0.371 & 125.9 & $0.001 * * *$ & 0.175 & 36.63 & $0.007 * * *$ \\
\hline At most 1 & 0.059 & 12.22 & 0.146 & 0.033 & 9.078 & 0.407 & 0.024 & 4.317 & 0.876 \\
\hline At most 2 & 0.012 & 2.036 & 0.153 & 0.003 & 0.728 & 0.547 & 0.001 & 0.321 & 0.705 \\
\hline
\end{tabular}

Note. This table presents the results of the Johansen Cointegration Test for implied interest rate (i*), the reported interest rate (id) and the inflation rate $(\pi)$ in the non-IT and IT periods for the countries that had not yet adopted inflation targeting between 1987 and $1997 . * * *, * *, *$ represents rejection of the null hypothesis at the 1,5 , and $10 \%$ level respectively, indicating the existence of at least one cointegrating relationship. 
Table 4. Johansen Cointegration test for IT countries between $i^{*}$ and inflation

\begin{tabular}{llllllllll}
\hline & \multicolumn{3}{l}{ Non-IT Period (XAD) } & \multicolumn{2}{l}{ Non-IT Period (XCD) } & \multicolumn{2}{c}{ Non-IT Period (XBP) } \\
\hline No. of CE(s) & Eigen & Trace & Prob. & Eigen & Trace & Prob. & Eigen & Trace & Prob. \\
\hline None & 0.035 & 9.239 & 0.589 & 0.059 & 14.420 & 0.165 & 0.050 & 31.437 & 0.228 \\
At most 1 & 0.001 & 0.149 & 0.768 & 0.012 & 2.308 & 0.129 & 0.001 & 7.427 & 0.926 \\
\hline \multicolumn{3}{l}{ IT Period (XAD) } & \multicolumn{5}{c}{ IT Period (XCD) } & \multicolumn{3}{c}{ IT Period (XBP) } \\
\hline No. of CE(s) & Eigen & Trace & Prob. & Eigen & Trace & Prob. & Eigen & Trace & Prob. \\
\hline None & 0.253 & 47.107 & $0.001 * * *$ & 0.039 & 16.685 & $0.085 *$ & 0.171 & 53.584 & $0.001 * * *$ \\
At most 1 & 0.061 & 8.379 & $0.004 * * *$ & 0.020 & 5.589 & $0.018^{* *}$ & 0.022 & 5.714 & $0.017 * *$ \\
\hline
\end{tabular}

Note. This table presents the results of the Johansen Cointegration Test for the implied interest rate (i*) and the inflation rate $(\pi)$ in the non-IT and IT periods for the countries that adopted inflation targeting between 1987 and 1997. ***, **, * represents rejection of the null hypothesis at the 1,5 , and $10 \%$ level respectively, indicating the existence of at least one cointegrating relationship.

Table 5. Johansen Cointegration test for control group between $i^{*}$ and inflation

\begin{tabular}{|c|c|c|c|c|c|c|c|c|c|}
\hline \multirow[b]{2}{*}{ No. of CE(s) } & \multicolumn{3}{|c|}{ 1987:1-1992:12(XDM) } & \multicolumn{3}{|c|}{ 1987:1-1992:12 (XJY) } & \multicolumn{3}{|c|}{ 1987:1-1992:12 (XCF) } \\
\hline & Eigen & Trace & Prob. & Eigen & Trace & Prob. & Eigen & Trace & Prob. \\
\hline None & 0.048 & 12.522 & 0.304 & 0.035 & 9.009 & 0.609 & 0.043 & 31.437 & 0.101 \\
\hline \multirow[t]{2}{*}{ At most 1} & 0.001 & 0.143 & 0.770 & 0.000 & 0.002 & 0.964 & 0.001 & 2.263 & 0.133 \\
\hline & \multicolumn{3}{|c|}{ 1993:1-1997:12 (XDM) } & \multicolumn{3}{|c|}{ 1993:1-1997:12 (XJY) } & \multicolumn{3}{|c|}{ 1993:1-1997:12 (XCF) } \\
\hline No. of CE(s) & Eigen & Trace & Prob. & Eigen & Trace & Prob. & Eigen & Trace & Prob. \\
\hline None & 0.050 & 15.533 & 0.121 & 0.045 & 11.813 & 0.365 & 0.094 & 27.015 & $0.003 * * *$ \\
\hline At most 1 & 0.009 & 2.262 & 0.133 & 0.003 & 0.796 & 0.552 & 0.014 & 3.322 & $0.068^{*}$ \\
\hline
\end{tabular}

Note. This table presents the results of the Johansen Cointegration Test for the implied interest rate (i*) and the inflation rate $(\pi)$ in the non-IT and IT periods for the countries that had not yet adopted inflation targeting between 1987 and 1997.***,**, * represents rejection of the null hypothesis at the 1,5 , and $10 \%$ level respectively, indicating the existence of at least one cointegrating relationship.

Based on the presence of at least one cointegrating relationship in the IT period/post-1993 period as seen in Tables 2 and 3, we proceed with the Vector Error Correction model (VECM 1) to test the dynamic relationship between implied interest rates $\left(i^{*}\right)$, reported domestic interest rates $\left(i_{d}\right)$, and the inflation rate $(\pi)$ for this period. We compare the $\alpha$ values derived from the VEC model in Equation (10) in the IT and non-IT periods, as well as for the control group, to determine whether the speed to convergence differs. Table 6 presents these values for all countries. In the IT countries (top), the higher absolute values for implied interest rates and inflation in the IT period indicate a faster speed to convergence once inflation targeting is adopted. The speed to convergence for the domestic interest rate improves in the IT period only in the UK.

Table 6. Speed to convergence based on VECM 1

\begin{tabular}{lllccccc}
\hline & \multicolumn{2}{c}{ Australia } & \multicolumn{2}{c}{ Canada } & \multicolumn{2}{c}{ United Kingdom } \\
\hline & Non-IT & IT & Non-IT & IT & Non-IT & IT \\
\hline$i^{*}$ & -0.071 & -0.079 & -0.039 & -0.054 & -0.037 & -0.075 \\
$i_{d}$ & 0.071 & 0.062 & 0.054 & 0.021 & 0.020 & 0.053 \\
$\pi$ & -0.014 & 0.035 & -0.010 & \multicolumn{2}{c}{0.037} & 0.054 & 0.059 \\
\hline & \multicolumn{2}{c}{ Germany } & \multicolumn{2}{c}{ Japan } & \multicolumn{2}{c}{ Switzerland } \\
\hline & $1987: 1-1992: 12$ & $1993: 1-1997: 12$ & $1987: 1-1992: 12$ & $1993: 1-1997: 12$ & $1987: 1-1992: 12$ & $1993: 1-1997: 12$ \\
\hline$i^{*}$ & 0.018 & -0.050 & 0.171 & -0.068 & - & -0.336 \\
$i_{d}$ & 0.029 & 0.020 & 0.419 & 0.453 & - & -0.065 \\
$\pi$ & -0.047 & -0.004 & -0.099 & -0.060 & - & -0.097 \\
\hline
\end{tabular}

Note. This table presents the speed to convergence coefficients from the VECM 1 for the IT countries and the control group. Since there is no cointegrating relationship present in the 1987:1-1992:12 period in Switzerland, it is not possible to run the VEC model and thereby obtain the $\alpha$ values.

The results are less clear for the control group (bottom). In both Germany and Japan, the implied interest rate begins to converge to equilibrium in the latter period (1993:1-1997:12). Convergence speed remains relatively consistent in the reported interest rate across the periods. For inflation, convergence speed slows in the latter period compared to the former period. Since Switzerland did not exhibit any cointegrating relationships among 
the three variables in 1987:1-1992:12, the VEC model cannot be run for this period, hence why no results are reported.

Next, we are interested in interpreting the responsiveness of the implied interest rate to innovations or shocks in the domestic interest rate and in inflation. To test this, we rely on the impulse response functions derived from the VEC model presented in Figures 3 and 4.

Figure 3 presents the impulse response functions for the IT countries once inflation targeting is adopted. The top graphs show the response of the implied interest rate $\left(i^{*}\right)$ to shocks in the domestic interest rate $\left(i_{d}\right)$ during the inflation targeting periods. Innovations in the domestic interest rate have consistent effects on marketexpectations across the three countries. Market expectations respond with persistently higherimplied interest rates after shocks to the domestic interest rate. In contrast, this is not seen in the control group in Figure 4 (except for Switzerland). In Germany, there is an immediate response by $i^{*}$ that dissipates quickly. There is virtually no response in the implied interest rate to a shock in the domestic interest rate in Japan. In Switzerland, the response mirrors that of the IT countries. As mentioned previously, although Switzerland did not formally adopt inflation targeting in this period, the monetary authority was openly committed to price stability and it enacted monetary policy that targeted the monetary base with the express purpose of maintaining price stability. In the Appendix, Figures 7 and 8 present the impulse response functions corresponding to the non-IT/pre-1993 period for the two groups of countries. The results remain consistent in the control group across the time periods. Yet for the IT countries, the response of $i^{*}$ to shocks in the domestic interest rate is slightly lower in the IT period compared to the non-IT period.

The middle graphs in Figures 3 and 4 show the response of the implied interest rate $\left(i^{*}\right)$ to shocks in the inflation rate $(\pi)$. In the IT countries, the implied interest rate has a limited response to shocks in inflation. The initial reaction of the implied interest rate to an inflation shock is for $i^{*}$ to increase. In Australia and the UK, after the initial increase in expectations in response to an inflation shock, $i^{*}$ remains at a permanently higher level. In Canada, after the initial increase in response to an inflation shock dissipates, market expectations on interest rates appear to decrease.

In Figure 4 for the control group, there is no significant response by the implied interest rate to inflation shocks in Japan. In Germany, after an initial increase, the expectations on interest rate movements actually decrease, similar to what is seen in Canada. In Switzerland, shocks to inflation lead to permanently lower expectations on interest rate movements, yet when considering the confidence intervals, the response appears neutral to inflation shocks.

Across both groups of countries in both periods, the domestic interest rate responds to a shock in expectations. The domestic interest rate appears to be permanently higher and increasing when there is a positive shock in market expectations on interest rate movements, seen in the bottom graphs of Figures 3 and 4.

We use the results of the VECM 1 model, along with the results of the VECM 2 and VAR models which are presented in the Appendix, to test the predictive power of the models in the inflation targeting/post-1993 period. Using static forecasting, we compare the 10 week forecast for the implied interest rate, domestic interest rate, and inflation rate with the reported values in the IT countries and control group.

Figure 5 presents the results for the 10 week forecast of $i^{*}$ (top), $i_{d}$ (middle), and inflation (bottom) for the three IT countries. In all three countries, the forecasted values of $i_{d}$ and inflation closely follow the trend in the reported values with a lag of one to two periods. In Australia and the UK, the forecast of the implied interest rate predicts the movement of the estimated implied interest rate one period ahead. In Canada, the forecast lags the estimated implied interest rate one period. Figures 10 and 11 confirm the ability of the models to provide forecastable values of $i^{*}$ and inflation that follow the trends in each variable using the VAR and VECM 2 models respectively.

Figure 6 presents the results for the 10 week forecast of $i^{*}$ (top), $i_{d}$ (middle), and inflation (bottom) for the three control group countries. In all three countries, the forecasted values of $i^{*}, i_{d}$ and inflation closely follow the trend in the reported values with a lag of one to two periods. This is confirmed with Figure 12 using forecasted values derived from the VAR model (Note 10). ${ }^{10}$ 

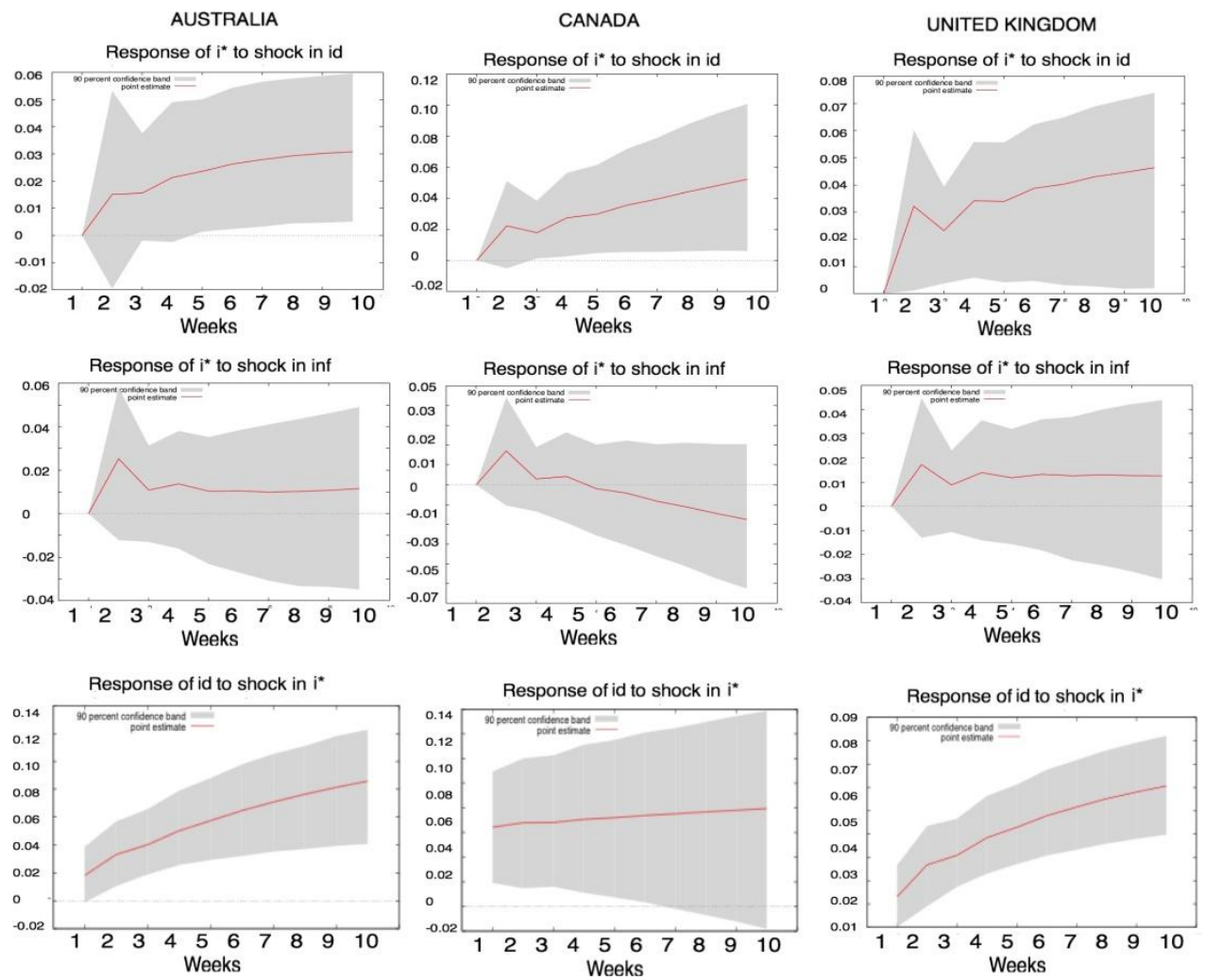

Figure 3. Impulse response functions for IT Countries (IT Period)

Note. This figure presents the response of the implied interest rates derived from the option price to domestic interest rate and inflation innovations based on VECM 1 for the period after adoption of inflation targeting. The 90 percent confidence intervals are bootstrapped.
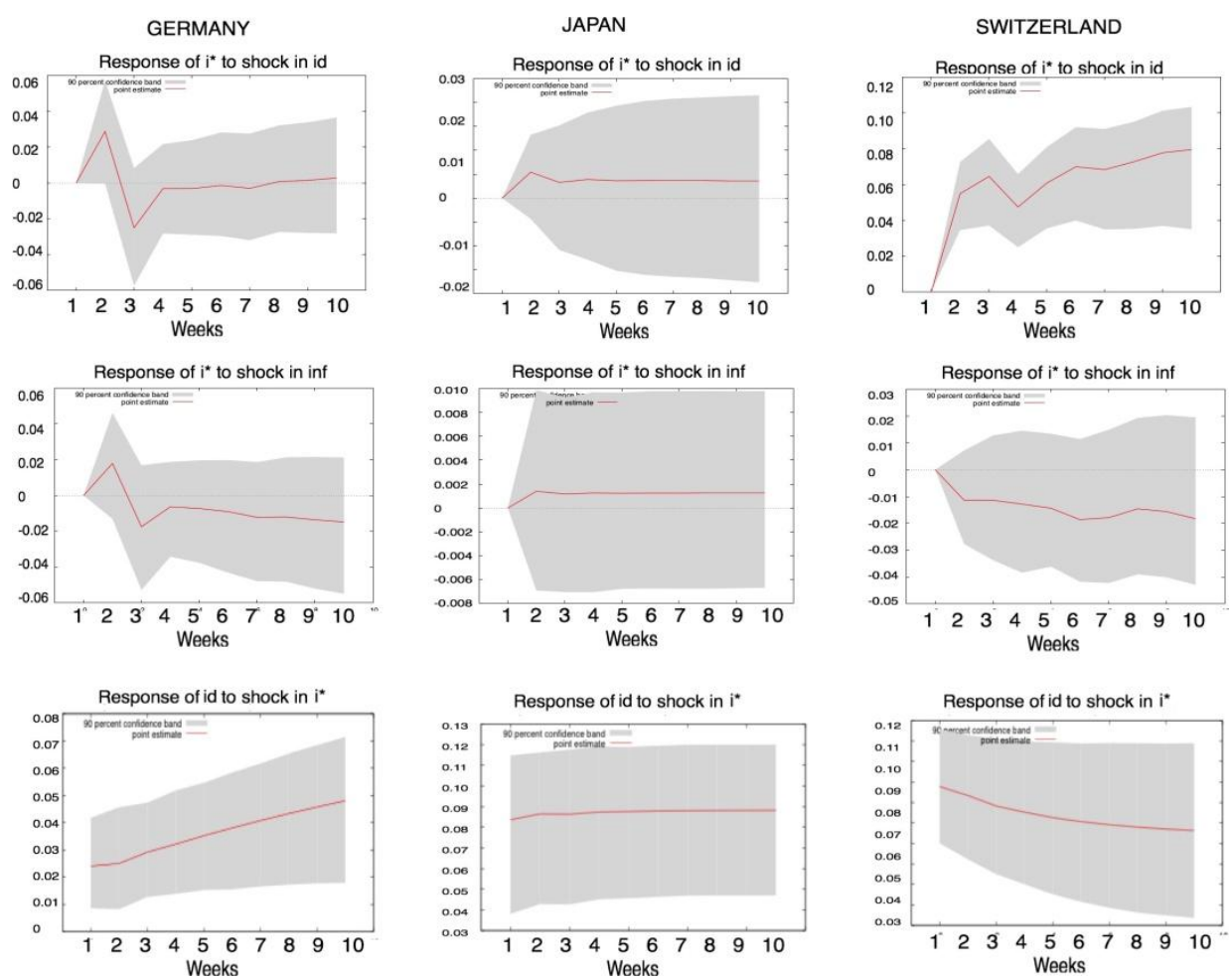

Figure 4. Impulse response functions for control group (1993:1 - 1997:12)

Note. This figure presents the response of the implied interest rates derived from the option price to domestic interest rate and inflation innovations based on VECM 1 for the period 1993:1 - 1997:12. The 90 percent confidence intervals are bootstrapped. 

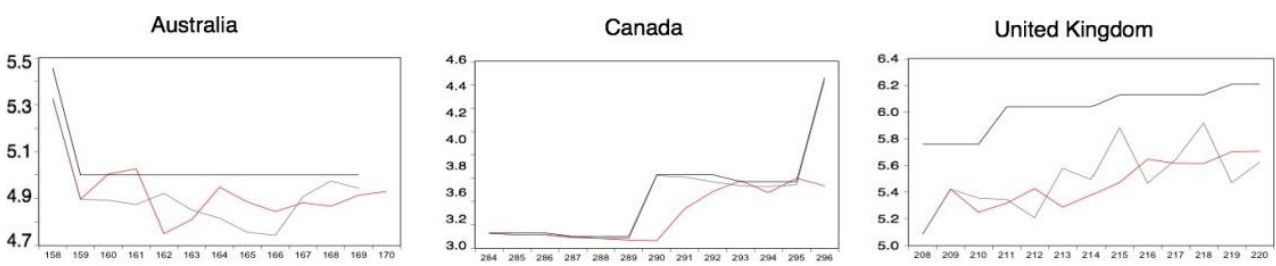

\section{— i (forecast) — i (estimate) —id (reported)}
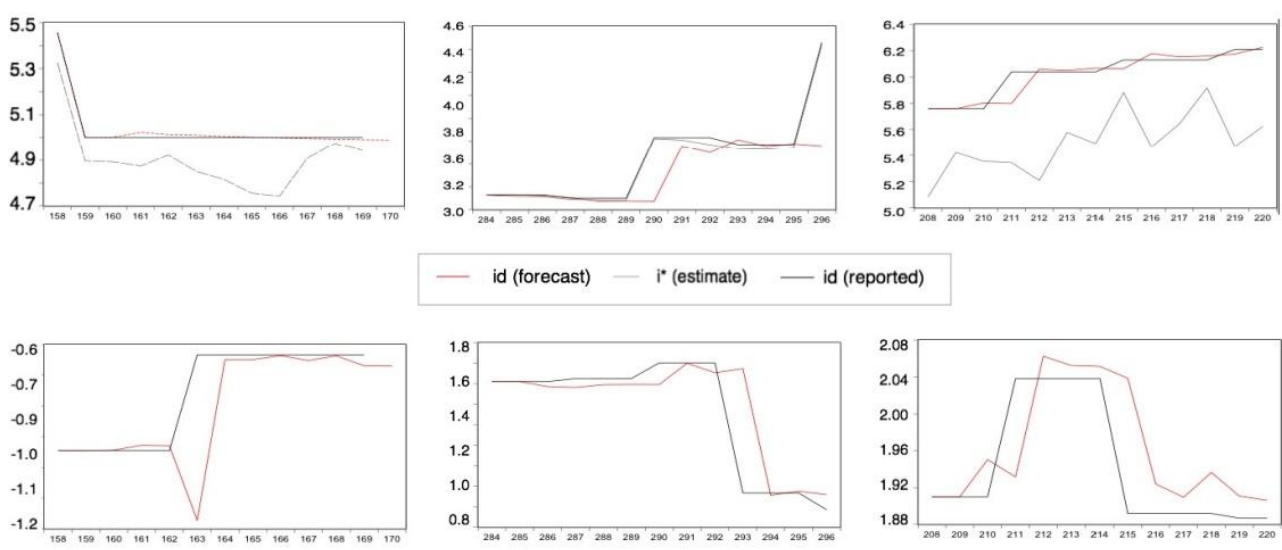

— inf (forecast) _ $\quad$ inf (reported)

Figure 5. Forecast of implied interest rates for IT countries

Note. This figure shows the forecasted values of the implied interest rate against the reported domestic interest rate using a 10-week forecast based on VECM 1.
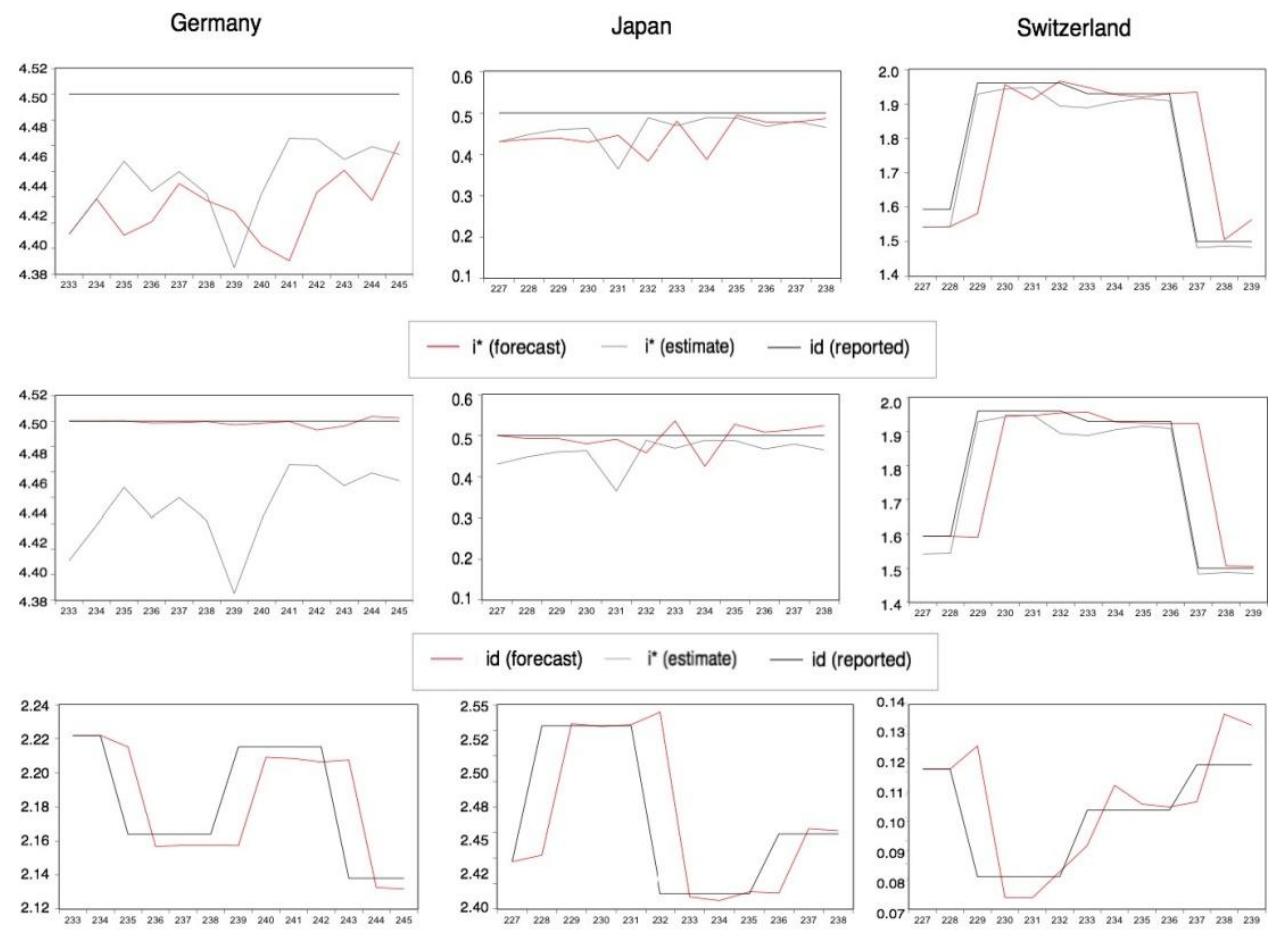

$$
\text { — id (forecast) — i* (estimate) —id (reported) }
$$
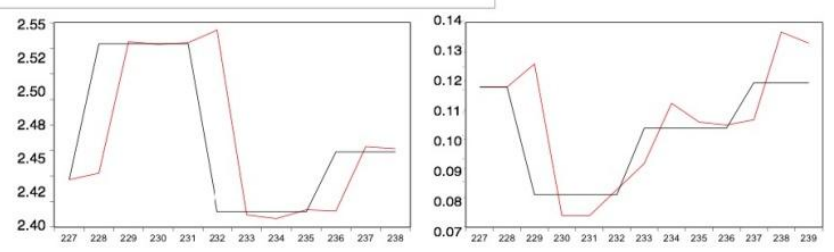

- inf (forecast) - inf (reported)

Figure 6. Forecast of implied interest rates for control group

Note. This figure shows the forecasted values of the implied interest rate against the reported domestic interest rate using a 10-week forecast based on VECM 1. 
There are a number of limitations that must be addressed. First, as discussed in the methodology section, we are restricted to using historical data from 1987-1997, which encompasses the start of inflation targeting in the countries under study. If options pricing data becomes more accessible, this study would benefit from comparing the implied interest rate outcomes from the options price to those from forward or futures contracts in recent years. Second, we are also restricted to using only advanced economies, which already have superior methods of gauging market sentiment on interest rate movements, such as the fed funds futures contracts. Since our findings may be most useful to emerging economies looking to expand options markets, this study is limited to interpretting the results for emerging economies only under a best-case scenario with developed financial markets, as well as transparent and credible monetary policy.

\section{Conclusions}

In this paper, we demonstrate how currency options factor in market expectations of interest rate movements and inflation into the options price. Using the Australian-US Dollar (XAD), the British Pound-US Dollar (XBP), and the Canadian-US Dollar (XCD) currency options data, we calculate the implied domestic interest rate between 1987 and 1997, segmenting the data into the non-inflation targeting and inflation targeting periods. We contrast the results for these countries that adopted inflation targeting during this period with three countries that did not: Germany, Japan and Switzerland.

From the results, we confirm that in fact currency options prices provide reliable insights on market expectations on interest rate movements through the implied interest rate measure. The estimated implied interest rates follow the trend of domestic interest rates across all countries, and closely replicate the reported values during periods of low inflation. The models provide forecastable values of the implied interest rate, domestic interest rate, and inflation rates that follow the trend in the reported values. Lastly, across all countries, the responsiveness of the implied interest rate to shocks in inflation and the domestic interest rate is slightly lower in the IT/post-1993 period. This may be attributed to greater proliferation and availability of currency options, and greater depth in the options markets.

Our findings contribute to the literature on the role of financial instruments in reflecting expectations of the market, tools that can be particularly valuable to policymakers as they attempt to regularly gauge market sentiment. Previously, currency options have been used only to gauge sentiment on future exchange rate volatility through the implied volatility measure. Our findings extend the usefulness of currency options and suggest that this is not the only piece of useful information to be extracted from the options price. With the proliferation of inflation targeting monetary policy, which has brought with it commitment to stable prices and transparent execution of monetary policy decisions, market participants are also factoring in expectations on interest rates and inflation expectations into the options price. Critically, our findings show that a long-run relationship between the currency option price and the inflation rate is established upon the adoption of inflation targeting monetary policy. Therefore, currency options are yet one more financial tool that can be used by policymakers to effectively gauge market sentiment on implied interest rate and inflation rate measures, in addition to expectations on currency movement.

This relationship between inflation, implied interest rates and currency options has not been addressed in the literature. Previous work has focused on futures or forward contracts, which are binding. Currency options provide more flexibility in terms of execution to market participants, and may therefore be more attractive for many. Furthermore, these findings are particularly important in emerging market economies. In recent years, these economies have used currency options as a foreign exchange intervention mechanism (Keefe \& Rengifo, 2015), or are interested in bolstering the growth and development of these risk markets in their economies. Welldeveloped financial markets, including derivatives and risk markets, are critical to ensuring sound economic growth and development, as excess funds are channeled into more productive purposes, transaction costs are lowered, and investment and savings grow. To date, options and derivatives markets in emerging market economies have been shallow, but growing quickly. Developing these markets can lead to enhanced economic efficiency and greater transparency in the financial system in general. Options are a powerful tool that can be leveraged by both market participants and policymakers to gauge market sentiments and interpret market expectations without relying on survey data that is released and collected at a low frequency.

Extensions of this research will focus on emerging market economies, as data on currency options in those countries becomes more readily available. As options markets continue to grow and deepen in emerging economies, it will be useful to test whether the same conclusions can be made as for the advanced economies presented in this paper, which have fully-developed financial markets. A second extension of this work is to test whether similar conclusions can be made using forward contracts, specifically in comparing the cointegration 
relationship between the inflation rate and forward versus options price.

\section{References}

Arizmendi, L. F. (2013). An Extended Model of Currency Options Applicable as a Policy Tool for Central Banks with Inflation Targeting and Dollarized Economies. Theoretical Economic Letters, 3, 164-167. https://doi.org/10.4236/tel.2013.33027

Bates, D. S. (1991). The Crash of 1987: Was It Expected? The Evidence from Options Markets. The Journal of Finance, 46, 1009-1044. https://doi.org/10.1111/j.1540-6261.1991.tb03775.x

Bomfim, A. (2003). Pre-Announcement Effects, News Effects, and Volatility: Monetary Policy and the Stock Market. Journal of Banking and Finance, 27, 133-151. https://doi.org/10.2139/ssrn.253062

Capistran, C., \& Ramos-Francia, M. (2010). Does Inflation Targeting Affect the Dispersion of Inflation Expectations? Journal of Money, Credit \& Banking, 42. https://doi.org/10.1111/j.1538-4616.2009.00280.x

Carlson, J. B., Craig, B. R., \& Melick, W. R. (2005). Recovering Market Expectations of FOMC Rate Changes with Options on Federal Funds Futures. Journal of Futures Markets, 25, 1203-1242. https://doi.org/10.1002/fut.20187

Cochrane, J. H., \& Piazzesi, M. (2002). The Fed and Interest Rates: A High Frequency Identification. American Economic Review Papers and Proceedings, 90-101. https://doi.org/10.1257/000282802320189069

Davis, J. S. (2014). Inflation Targeting and the Anchoring of Inflation Expectations: Cross-country Evidence from Consensus Forecasts. Federal Reserve Bank of Dallas Working Paper Globalization and Monetary Policy Institute, 174. https://doi.org/10.24149/gwp174

Ellingsen, T., \& Soderstrom, U. (2004). Monetary Policy and the Bond Market. Working Paper, IGIER. https://doi.org/10.1.1.379.6113

Faust, J., Swanson, E., \& Wright, J. H. (2004). Identifying VARs Based on High Frequency Futures Data. Journal of Monetary Economics, 51, 1107-1131. https://doi.org/10.1016/j.jmoneco.2003.11.001

Federal Reserve Bank of New York. (1997). German Monetary Targeting: A Precursor to Inflation Targeting. Federal Reserve Bank of New York Economic Policy Review. Retrieved from https://www.newyorkfed.org/medialibrary/media/research/epr/97v03n3/9708part3.pdf

Garman, M. B., \& Kohlhagen, S. W. (1983). Foreign Currency Option Values. Journal of International Money and Finance, 2. https://doi.org/10.1016/S0261-5606(83)80001-1

Gurkayank, R. S., Sack, B. P., \& Swanson, E. T. (2007). Market-Based Measures of Monetary Policy Expectations. Journal of Business \& Economic Statistics, 25, 201-212. https://doi.org/10.1198/073500106000000387

Han, Q., Liang, J., \& Wu, B. (2016). Cross Economic Determinants of Implied Volatility Smile Dynamics: Three Major European Currency Options. European Financial Management, 22(5). https://doi.org/10.1111/eufm.12072

Hong, H., \& Yogo, M. (2012). What Does Futures Market Interest Tell Us About the Macroeconomy and Asset Prices? Journal of Financial Economics, 105(3), 473-490. https://doi.org/10.1016/j.jfineco.2012.04.005

Hui, C. H., \& Fong, T. P. W. (2015). Price Cointegration between Sovereign CDS and Currency Option Markets in the Financial Crises of 2007-2013. International Review of Economics and Finance, 40. https://dx.doi.org/10.2139/ssrn.1977376

Keefe, H. G., \& Rengifo, E. W. (2015). Options and Central Bank Currency Market Intervention: The Case of Colombia. Emerging Markets Review, 23. https://doi.org/10.1016/j.ememar.2015.04.011

Kumar, S., Afrouzi, H., Coibion, O., \& Gorodnichenko, Y. (2015). Inflation Targeting Does Not Anchor Inflation Expectations: Evidence from Firms in New Zealand. Brookings Papers on Economic Activity. https://doi.org/10.1353/eca.2015.0007

Kuttner, K. (2001). Monetary Policy Surprises and Interest Rates: Evidence From the Fed Funds Futures Market. Journal of Monetary Economics, 47, 523-544. https://doi.org/10.2139/ssrn.933694

Mishkin, F. S., \& Posen, A. S. (1998). Inflation Targeting: Lessons from Four Countries. NBER Working Paper Series 6125. https://doi.org/10.3386/w6126

Molodtsova, T., \& Papell, D. (2012). Taylor Rule Exchange Rate Forecasting During The Financial Crisis. 
National Bureau of Economic Research. https://doi.org/10.3386/w18330

Poole, W., \& Rasche, R. H. (2000). Perfecting the Market's Knowledge of Monetary Policy. Journal of Financial Services Research, 18, 255-298. https://doi.org/10.1023/A:102655

Rich, G. (2003). Swiss Monetary Targeting 1974-1996: The Role of Internal Policy Analysis. European Central Bank Working Paper Series. from https://www.ecb.europa.eu/pub/pdf/scpwps/ecbwp236.pdf?384c32313db43a165ef9b969aea8db4d

Rigobon, R., \& Sack, B. (2002). The Impact of Monetary Policy on Asset Prices. National Bureau of Economic Research Working Paper 8794. https://doi.org/10.3386/w8794

Sihvonen, J., \& Vahamma, S. (2014). Forward-Looking Monetary Policy Rules and Option-Implied Interest Rate Expectations. The Journal of Futures Markets, 34. https://doi.org/10.1002/fut.21596

Soderlind, P., \& Svensson, L. E. O. (1997). New Techniques to Extract Market Expectations from Financial Instruments. NBER Working Paper 5877. https://doi.org/10.3386/w5877

Taylor, J. (1993). Discretion versus Policy Rules in Practice. Carnegie-Rochester Conference Series on Public Policy, 39. https://doi.org/10.1016/0167-2231(93)90009-L

Vähämaa, S., Watzka, S., \& Aijö, J. (2005). What Moves Option - Implied Bond Market Expectations? Journal of Futures Markets, 25, 817-843. https://doi.org/10.1002/fut.20164

\section{Notes}

Note 1. Surveys on market expectations of inflation are gathered monthly, if not quarterly, for most economies.

Note 2. Author's calculations.

Note 3. All currency options are against the US dollar.

Note 4. Currency options data for emerging economies is limited. Data is not available through traditional academic sources such as Bloomberg, WRDS, IFS, or other databases. Access to data from private sources, such as CME Group, is prohibitively expensive. Furthermore, currency options markets in emerging economies are still developing and tend to be shallow. Therefore, traditional pricing models, such as the Garman-Kohlhagen model, may not be able to provide the same quality of insights as for advanced economies with deep financial markets, developed options trading, and strong monetary institutions. We use the advanced economies as proxies for "best case scenarios" in emerging markets once financial and risk markets are fully developed and options trading is well established. A full explanation of data and limitations is presented in Section 3.

Note 5. Many advanced and emerging market economies rely on survey-based responses from businesses and consumers to determine inflation expectations. For example, the US uses the Survey of Professional Forecasters, a group that closely tracks the economic activity, to determine expectations for future inflation. Alternatively, and where available, central bankers can rely on market-based measures, such as the Treasury Inflation-Protected Securities.

Note 6. Gaps between the non-IT and IT periods are due to gaps in the available data through the WRDS database.

Note 7. We report the results based on the call price options. As a robustness test, we have also analyzed based on put prices, results are consistent and available upon request.

Note 8 . We have also tested using other measures of volatility, including implied volatility. Results remain consistent. Results available upon request

Note 9. Although it is typical to compare static and dynamic forecasts, along with forecasts based on ARIMA models, such comparison is outside of the scope of this paper, which is to demonstrate whether and to what degree currency option premiums can offer an inference on market expectations of interest rate movements. We employ the static forecasting as part of the results that show how currency options can be used by policymakers.

Note 10. The VECM 2 model is not available for the control group since there no cointegrating relationship was found between the implied interest rate and inflation. See Table 5. 


\section{Appendix}

AUSTRALIA

Response of $\mathrm{i}^{*}$ to shock in id
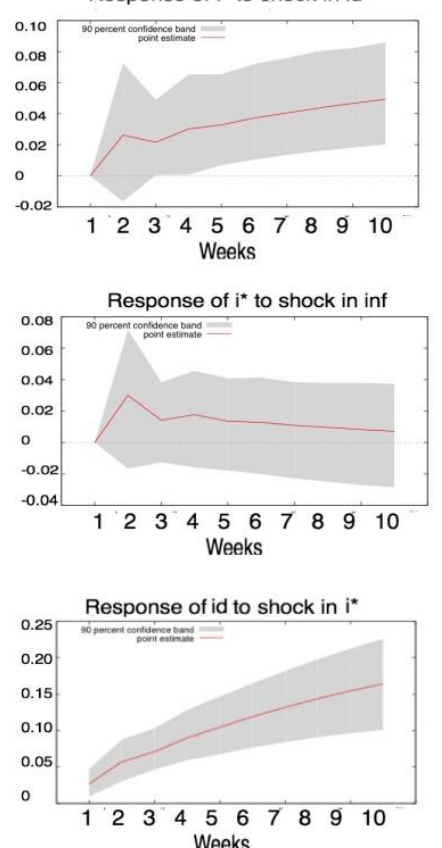

CANADA
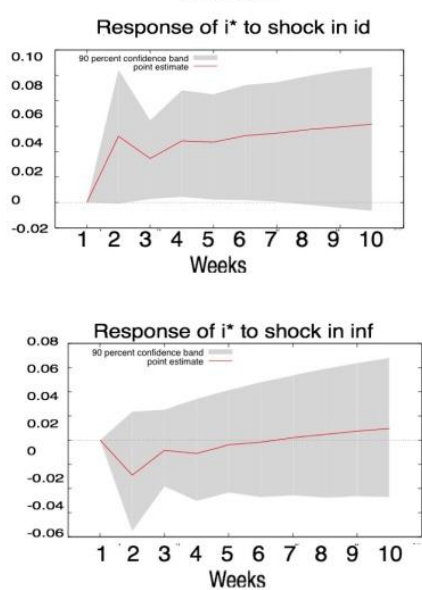

Response of id to shock in $i^{\star}$

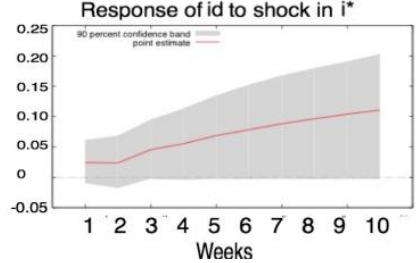

UNITED KINGDOM
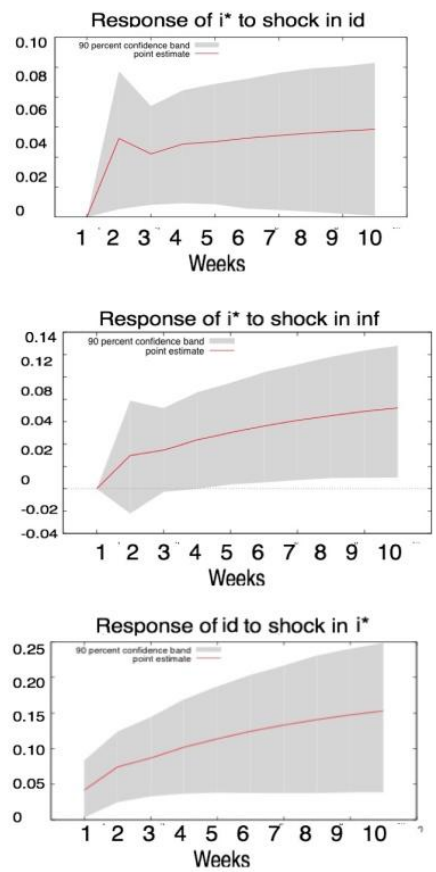

Figure 7. Impulse response functions for IT countries (Non-IT Period)

Note. This figure presents the response of the implied interest rates derived from the option price to domestic interest rate and inflation innovations based on VECM 1 for the period before the adoption of inflation targeting. The 90 percent confidence intervals are bootstrapped

GERMANY
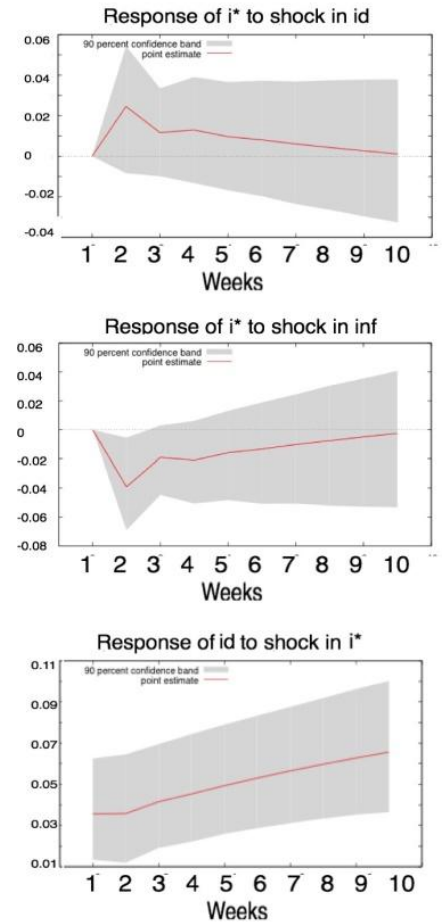

JAPAN
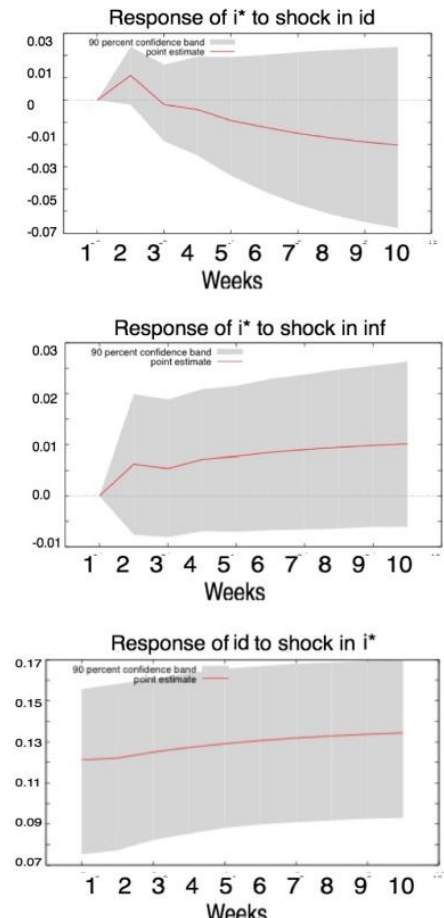

Figure 8. Impulse response functions for control group (1987:1 - 1992:12)

Note. This figure presents the response of the implied interest rates derived from the option price to domestic interest rate and inflation innovations based on VECM 1 for the period 1987:1 - 1992:12. The 90 percent confidence intervals are bootstrapped. 
AUSTRALIA
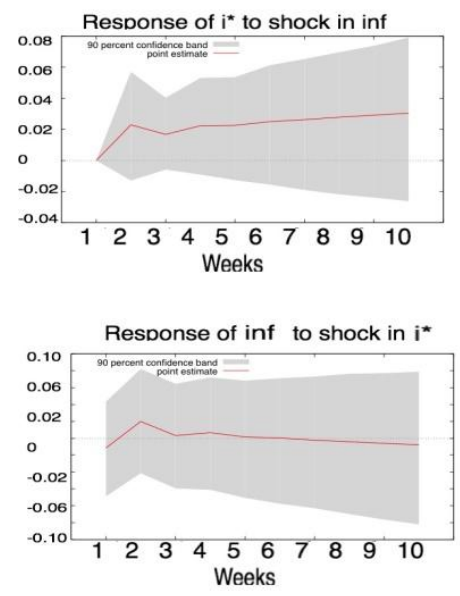

CANADA
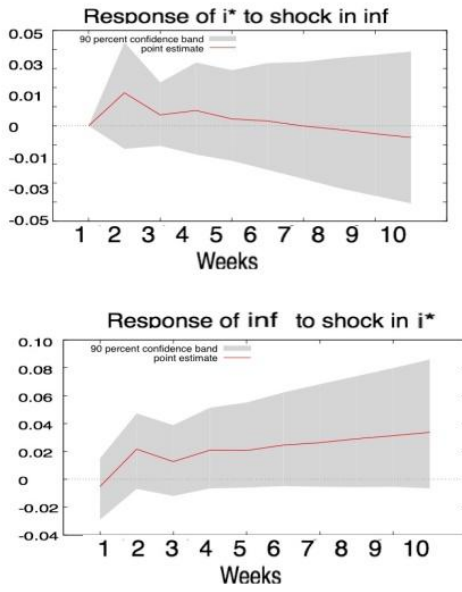

UNITED KINGDOM

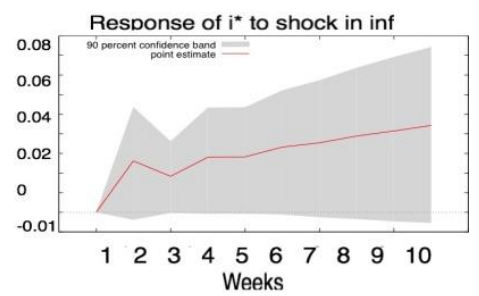

Response of inf to shock in $\mathrm{i}^{\star}$

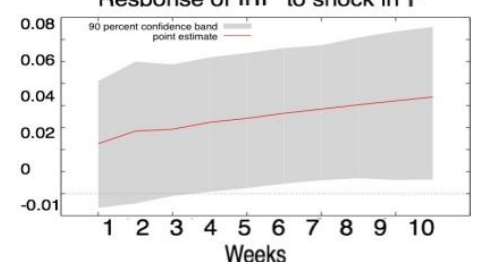

Figure 9. Impulse response functions for IT countries based on VECM 2

Note. This figure presents the response of the implied interest rates derived from the option price to inflation innovations based on VECM 2 for the period after adoption of inflation targeting. The 90 percent confidence intervals are bootstrapped.

Australia

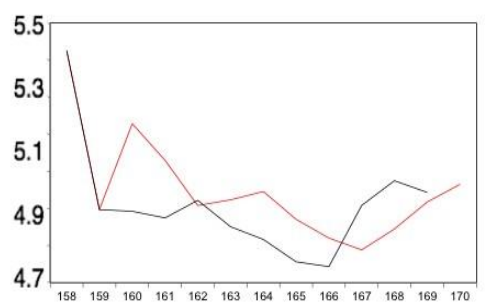

Canada

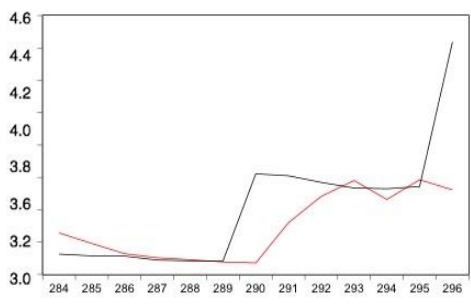

United Kingdom

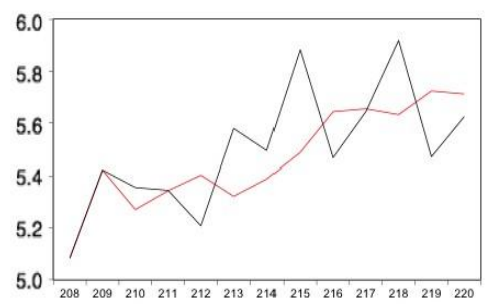

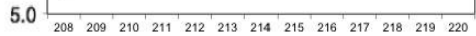

\section{$\mathrm{i}^{*}$ (forecast) $\quad \mathrm{i}^{\star}$ (estimate) $\quad$ id (reported)}
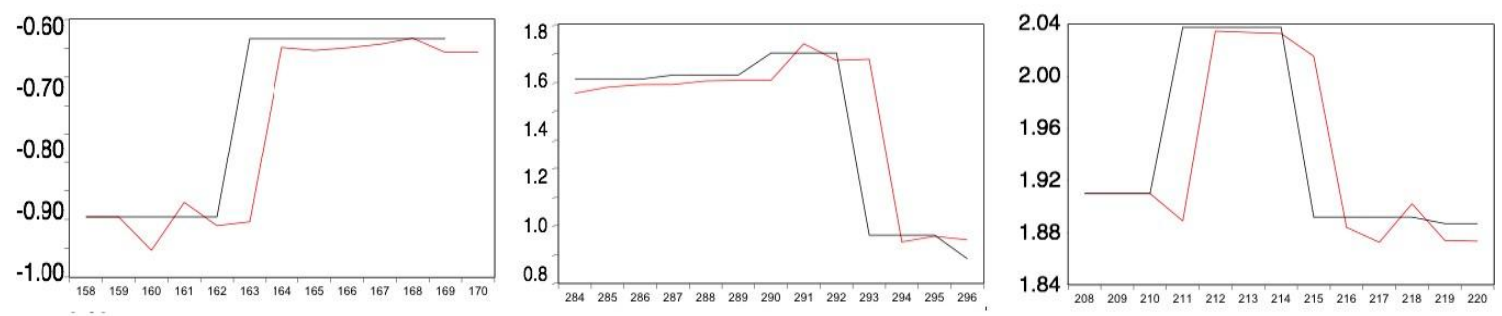

— inf (forecast) - inf (reported)

Figure 10. Forecast of implied interest rates for IT countries based on VAR

Note. This figure shows the forecasted values of the implied interest rate against the reported domestic interest rate using a 10-week forecast based on VAR. 
Australia

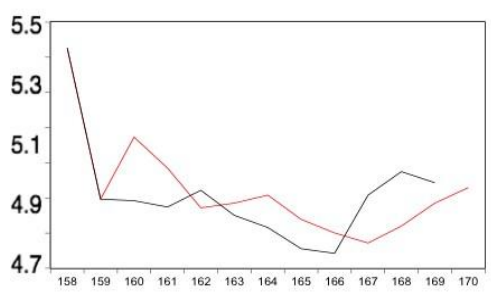

Canada

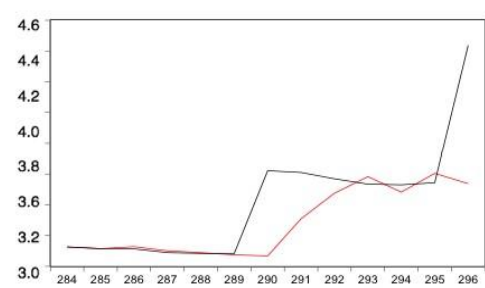

United Kingdom

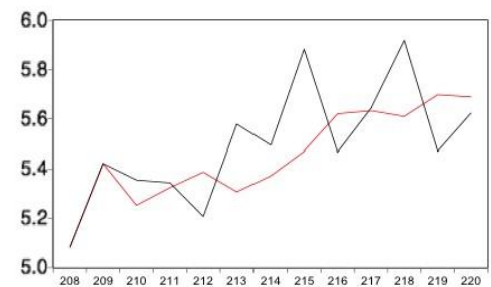

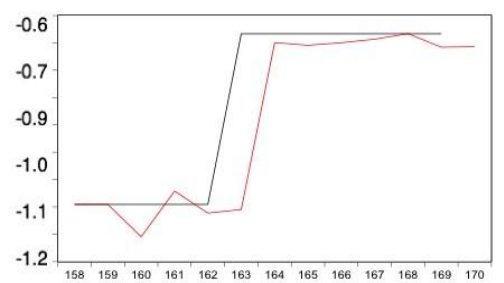
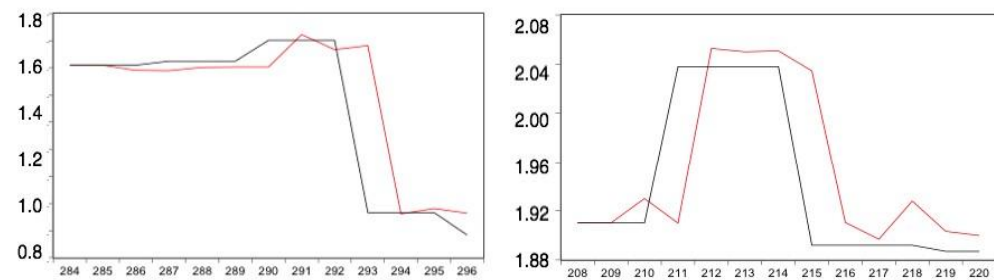

— inf (forecast)

— inf (reported)

Figure 11. Forecast of implied interest rates for IT countries based on VECM 2

Note. This figure shows the forecasted values of the implied interest rate against the reported domestic interest rate using a 10-week forecast based on VECM 2.
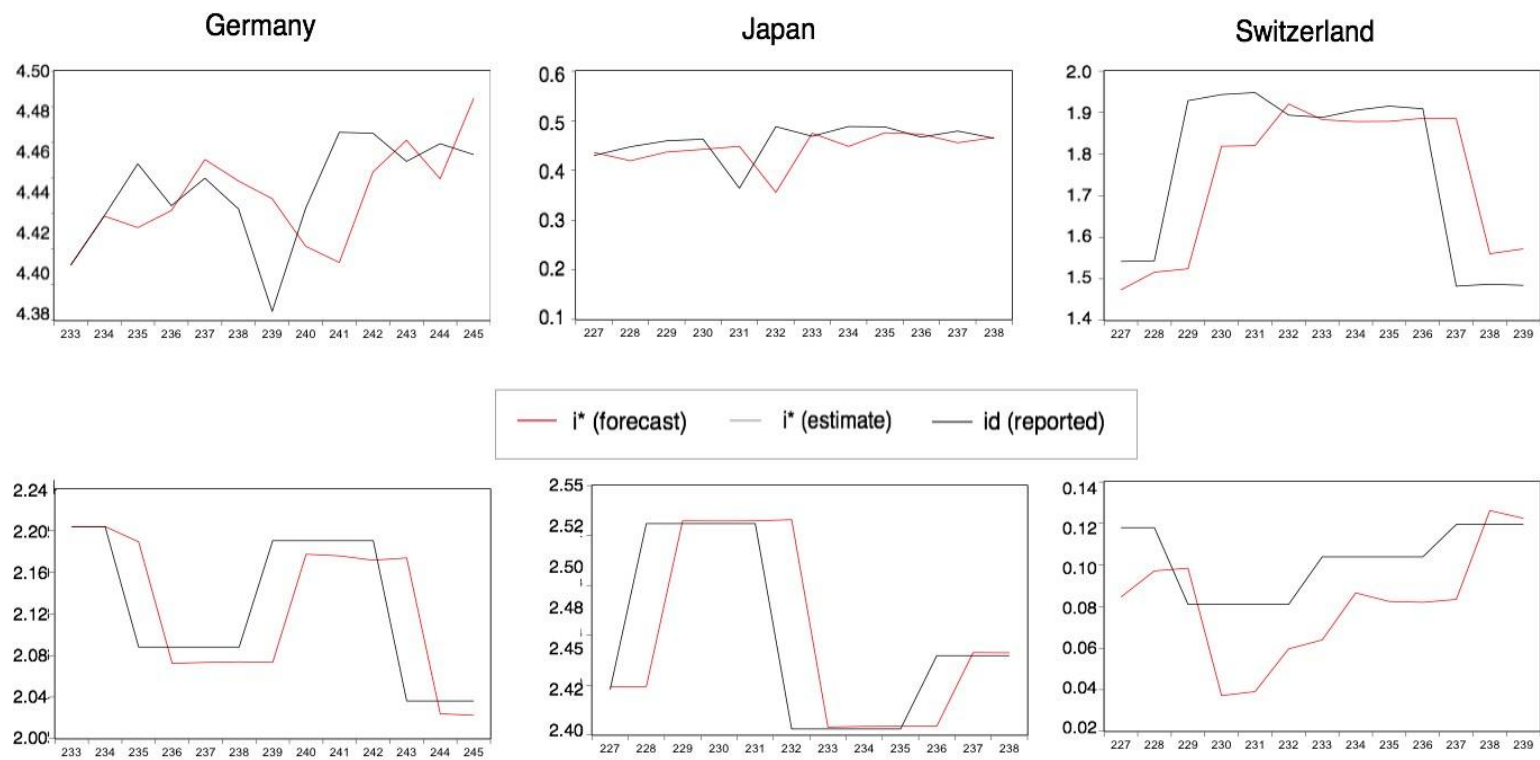

$$
\text { - i* (forecast) } \quad \mathrm{i}^{*} \text { (estimate) } \quad \text { id (reported) }
$$

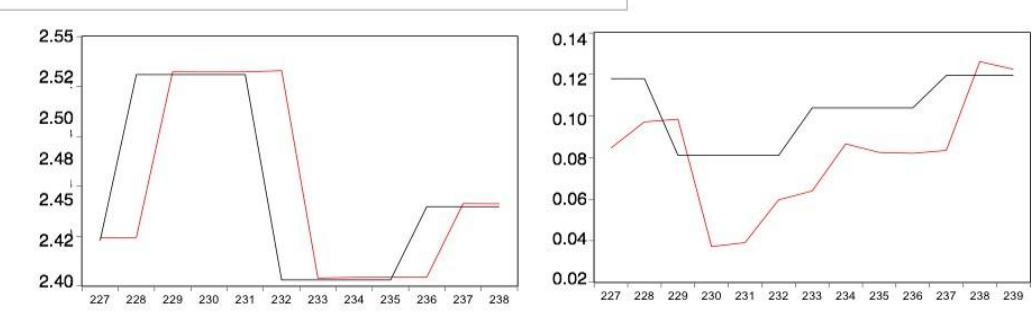

— inf (forecast) _ inf (reported)

Figure 12. Forecast of implied interest rates for control group based on VECM 2

Note. This figure shows the forecasted values of the implied interest rate against the reported domestic interest rate using a 10-week forecast based on VECM 2.

\section{Copyrights}

Copyright for this article is retained by the author(s), with first publication rights granted to the journal.

This is an open-access article distributed under the terms and conditions of the Creative Commons Attribution license (http://creativecommons.org/licenses/by/4.0/). 